\title{
Outline of the Problem of Energy Poverty in Poland - Trend and Extent
}

\author{
Arkadiusz PIWOWAR
}

Wroclaw University of Economics and Business, Wrocław, Poland; arkadiusz.piwowar@ue.wroc.pl

\begin{abstract}
Energy poverty is a social and economic phenomenon that consists in experiencing difficulties in meeting basic energy needs. This paper presents analyses of trends and current status in this respect in Poland. Statistical data of the Central Statistical Office in Poland and Eurostat provided the basis for this study. The analyses were carried out in the period of 2007-2017. The analyses show that an improvement in the extent of poverty and energy exclusion in Poland took place in the investigated period. However, a significant percentage of the population still struggles with problems related to energy poverty, such as maintaining an appropriate air temperature in living quarters and paying for electricity. It is necessary not only to continue to build awareness among local and national authorities and to monitor the situation, but also to create scenarios for the expected increase in electricity prices. Particular attention should be paid to helping the economically weakest households.
\end{abstract}

Keywords: energy poverty; expenditures on energy; family economics; Poland

JEL Classification: Q41; D10; G50

\section{Introduction}

Poverty and research on poverty are very important elements of knowledge and economic science; (Santos et al. 2019; Zhang and Naceur 2019). The topicality of issues related to poverty and social exclusion in economic sciences is proved, inter alia, by the Nobel Prize in Economics awarded in 2019. Esther Duflo, Abhijitem Banerjee and Michael Kremer received the prize for using an experimental approach for reducing the poverty in the entire world. Also in 2015, the Nobel Prize in economic sciences was awarded for the analysis of issues of consumption, poverty and prosperity (Angus Deaton). The problem of poverty can be considered in macro, meso and microeconomic aspects. Both analyses from a broad perspective (from the perspective of the entire world, continents and countries) and those on a regional and local scale are important (Charlier and Legendre 2019; Marchand et al. 2019).

The subject of this study concerns the poverty in Poland. The analyses of this phenomenon in this region have over a hundred years of tradition (the 1820s) (Panek 2008). Regardless of the methodological framework adopted, the analysis of the extent of poverty is an important factor when taking measures in the area of social policy. Reducing the poverty in urban and rural through the implementation of effective and inclusive policies and strategies is a major political challenge in each country (Romero et al. 2018; Pojar 2018; Adusah-Poku and Takeuchi 2019; Tàbara et al. 2019). According to statistical data, in $2017,112.8$ million people in the EU lived in households at risk of poverty or social exclusion $(22.4 \%$ of the population). In Poland, this problem affected 19.5\% of citizens, i.e. 7.3 million people.

A specific type of poverty is energy poverty. This type of poverty is associated with the problem of meeting energy needs: heating, hot water and electricity (Dagoumas and Kitsios 2014, González-Eguino 2015; Maxim et al. 2016; Aristondo and Onaindia 2018). Therefore, this issue concerns the basic needs of both biological and social functioning. Undoubtedly, energy poverty is strongly associated with poverty understood in an economic way (deprivation of access to material goods and resources). The literature of the subject mentions various types of causes of energy poverty. According to Węglarz at al. (2014), in addition to economic reasons, the technical and functional reasons (also known as behavioural, cognitive or emotional reasons) are also important. The problem of energy poverty is multidimensional (Santos et al. 2019). This phenomenon has negative consequences for cognitive development, health or even life. 
The literature of the subject emphasizes the issue of the social and health costs of energy poverty and its relation to the problem of air pollution. Energy poverty is associated with social exclusion (Jász 2010; Libor and Bouzarovski 2018). As part of the analysis of the subject matter, there can be indicated, inter alia, a positive correlation between energy consumption per capita and gross domestic product (GDP) (Brown et al. 2011). The issue of energy poverty is closely related to the inefficient functioning of sociotechnical paths that allow meeting the energy needs of households (Bouzarovski and Petrova 2015).

The main purpose of this paper is to estimate and demonstrate the variability of the extent of energy poverty in Poland (in various methodological breakdowns, described later in this paper). The analyses concerned not only the issues of internal variability (in Poland), but also partly the comparison of the phenomenon in Poland in relation to other countries in the European Union.

\section{Material and Research Methods}

This paper analyses statistical data both from the Central Statistical Office in Poland and Eurostat. The indicators presented in Table 1 were used for the analyses.

Table 1. A set of indicators used in this study to analyse the problems of energy poverty. (Energy Poverty Observatory 2019a)

\begin{tabular}{cc}
\hline \multicolumn{1}{c}{ Indicator } & Description \\
\hline Arrears on utility bills & $\begin{array}{c}\text { The share of (sub-) population having arrears on utility bills, based on } \\
\text { question "In the last twelve months, has the household been in arrears, } \\
\text { i.e. has been unable to pay on time due to financial difficulties for } \\
\text { utility bills (heating, electricity, gas, water, etc.) for the main } \\
\text { dwelling?" }\end{array}$ \\
\hline $\begin{array}{c}\text { Inability to keep home } \\
\text { adequately warm }\end{array}$ & $\begin{array}{c}\text { The share of (sub-) population not able to keep their home adequately } \\
\text { warm, based on question "Can your household afford to keep its home } \\
\text { ad-risk-of-poverty rate }\end{array}$ \\
$\begin{array}{c}\text { The share of people with an equivalised disposable income (after } \\
\text { social transfer) below the at-risk-of-poverty threshold, which is set at } \\
60 \text { of the national median equivalised disposable income after social } \\
\text { transfers. }\end{array}$
\end{tabular}

The first two indicators are among the four basic indicators in the investigated subject matter analysed by the EU Energy Poverty Observatory. In turn, the at-risk-of-poverty rate (after inclusion of social transfers) is defined as the percentage of people whose equivalent disposable income is less than the at-risk-of-poverty threshold (expressed in purchasing power standard - PPS) set at the level of $60 \%$ of the national median of the equivalent disposable income. This indicator is also one of the basic indicators in the investigated problem area. In addition, there were presented analyses concerning the relationships between income and expenditures associated with the purchase of energy in households in Poland. The main time range of the analyses covered the period of 2007-2017.

\section{Results and Discussion}

Eurostat data for 2017 show that $19.5 \%$ of the population in Poland was at risk of poverty and social exclusion. On the EU scale, this placed Poland on the 12th position among all EU-28 countries counting from the country with the lowest scale of this problem (Fig. 1). 


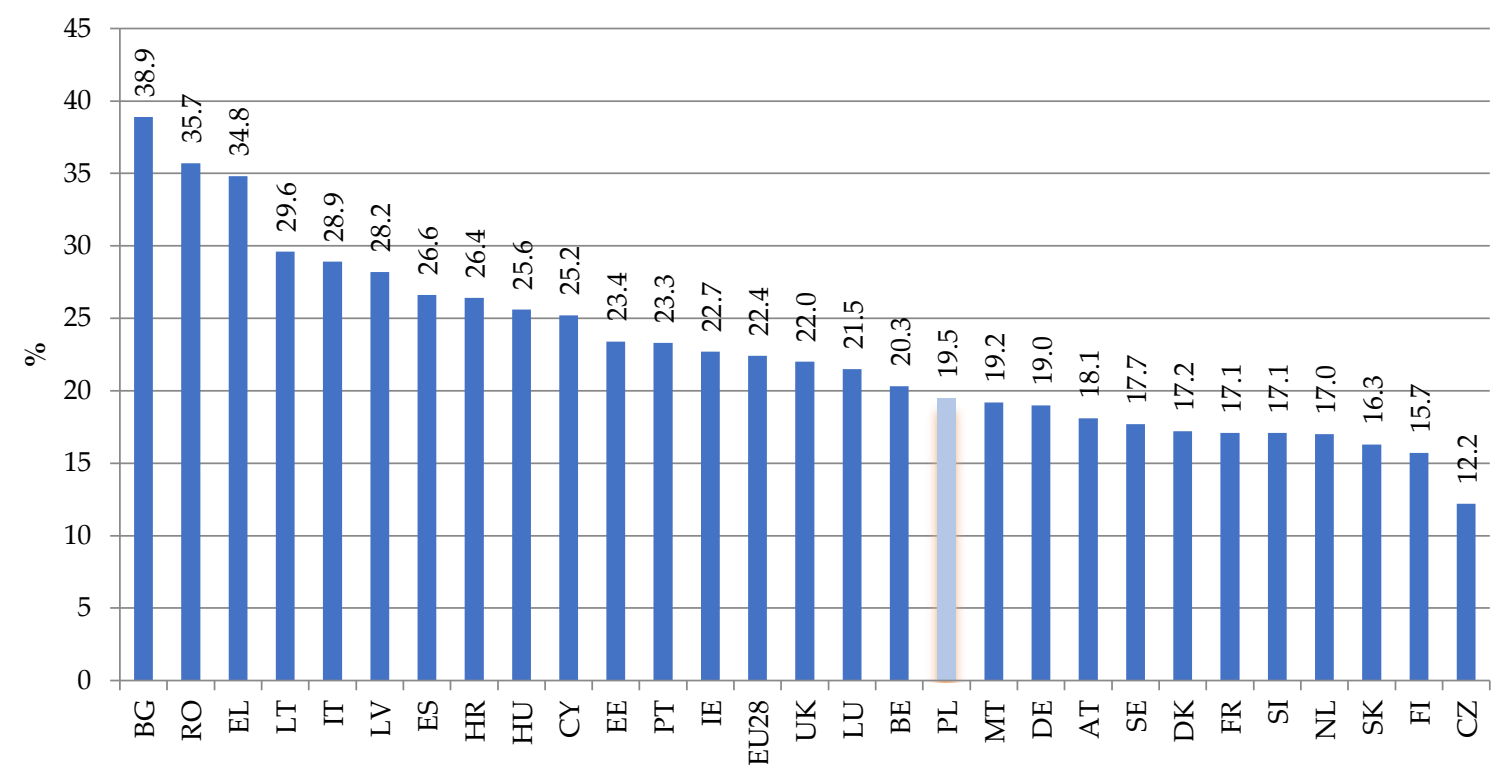

Figure 1. Share of the total population at risk of poverty or social exclusion by country in 2017. (Eurostat 2019b)

The lowest risk among all countries in the European Union was in the Czech Republic (12.2\%), while the highest - in Bulgaria (38.9\%). The main purpose of this paper is to show the scale and changes in the phenomenon of the poverty in Poland, hence it is worth noting that the value of this indicator keeps decreasing (Fig. 2).

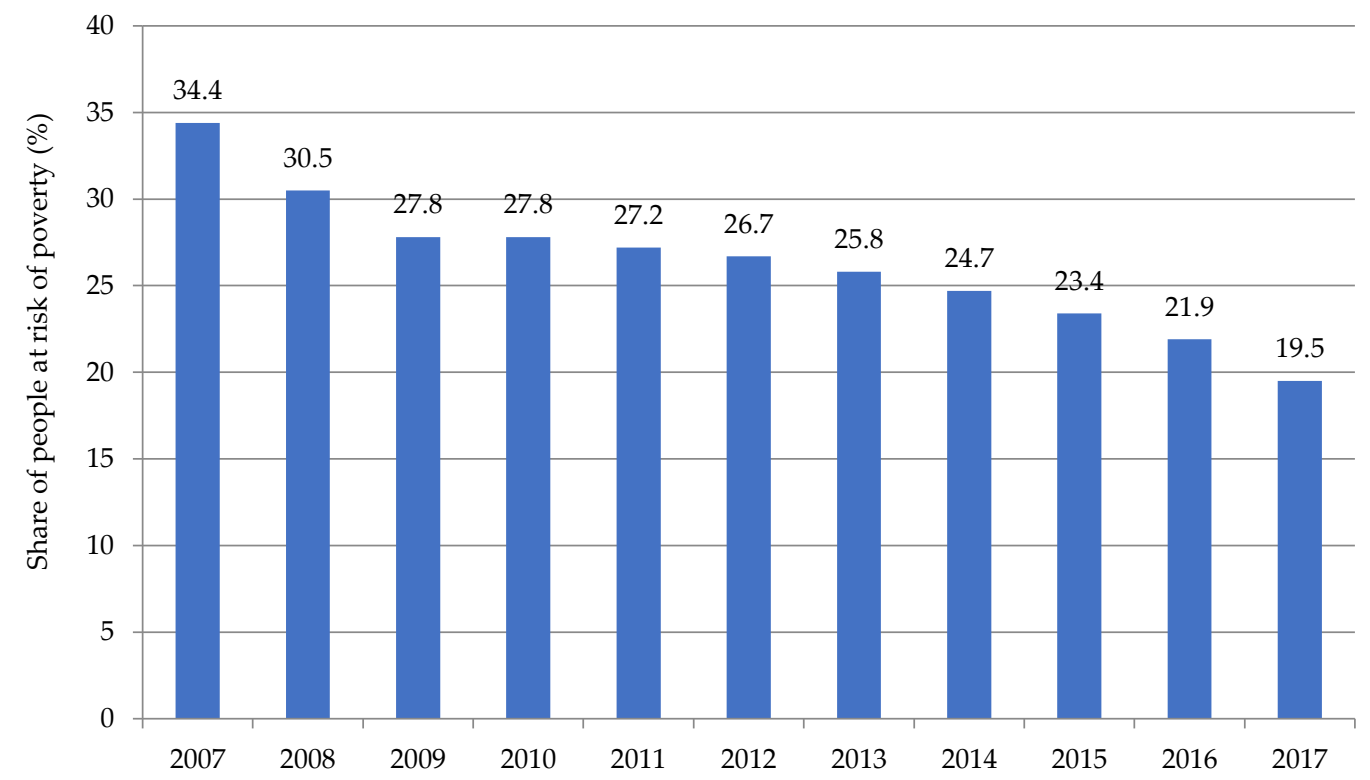

Figure 2. Share of people at risk of poverty or social exclusion in the total population of Poland from 2007 to 2017. (Eurostat 2019a)

The possibility of satisfying basic energy needs in the place of residence is related to the income and costs of purchasing energy carriers. Relations between expenditures (expenditures on energy in relation to the total expenditures) and between incomes and expenditures on energy purposes are important (Table 2). 
Table 2. Expenditures on energy purposes in relation to the total expenditures and incomes of a statistical household per capita in Poland in 2007-2017. (Statistic Poland 2019a; Statistic Poland 2019b)

\begin{tabular}{cccccccccccc}
\hline Specification & 2007 & $\mathbf{2 0 0 8}$ & $\mathbf{2 0 0 9}$ & $\mathbf{2 0 1 0}$ & $\mathbf{2 0 1 1}$ & $\mathbf{2 0 1 2}$ & $\mathbf{2 0 1 3}$ & $\mathbf{2 0 1 4}$ & $\mathbf{2 0 1 5}$ & $\mathbf{2 0 1 6}$ & $\mathbf{2 0 1 7}$ \\
\hline $\begin{array}{c}\text { Expenditures } \\
\text { (PLN) }\end{array}$ & 809.9 & 904.3 & 956.7 & 991.4 & 1015.1 & 1050.8 & 1061.7 & 1078.7 & 1091.2 & 1131.6 & 1176.4
\end{tabular}

\begin{tabular}{l}
$\begin{array}{c}\text { Expenditures } \\
\text { on energy - } \\
\text { electricity, } \\
\text { gas and } \\
\text { other fuels } \\
\text { (PLN) }\end{array}$ \\
\hline
\end{tabular}

$\begin{gathered}\text { Expenditures } \\ \text { on energy / } \\ \text { expenditures } \\ (\%)\end{gathered}$
$\begin{gathered}(\%) \\ \text { (1) }\end{gathered}$

\begin{tabular}{|c|c|c|c|c|c|c|c|c|c|c|c|}
\hline $\begin{array}{c}\text { Available } \\
\text { income } \\
(\mathrm{PLN})\end{array}$ & 929 & 1046 & 1114 & 1201 & 1235 & 1278 & 1299 & 1340 & 1386 & 1475 & 1598 \\
\hline $\begin{array}{c}\text { Expenditures } \\
\text { on energy / } \\
\text { available } \\
\text { income (\%) }\end{array}$ & 9.1 & 9.2 & 9.7 & 9.8 & 10.1 & 10.0 & 10.0 & 9.2 & 9.0 & 8.3 & 7.9 \\
\hline
\end{tabular}

The causes of energy poverty should be seen, inter alia, in low incomes of households and high prices of energy, often resulting in an increase in consumer debt beyond their income capabilities. As it results from analyses, the expenditures on energy in Poland (statistical household per capita) in 2017 accounted for $10.7 \%$ of the total expenditures. A downward trend regarding this indicator has been observed in Poland since 2013. The share of expenditures on energy in the disposable income also becomes lower and lower. The lowest level of this indicator in the entire investigated period was recorded in 2017. Along with an increase in income, the share of expenditures on energy in the structure of the total expenditures decreases.

Subjective measures of energy poverty include also answers to questions about difficulties in maintaining an adequate temperature in the place of residence as well as problems with paying for the energy supplied to the household (Fig. 3). 


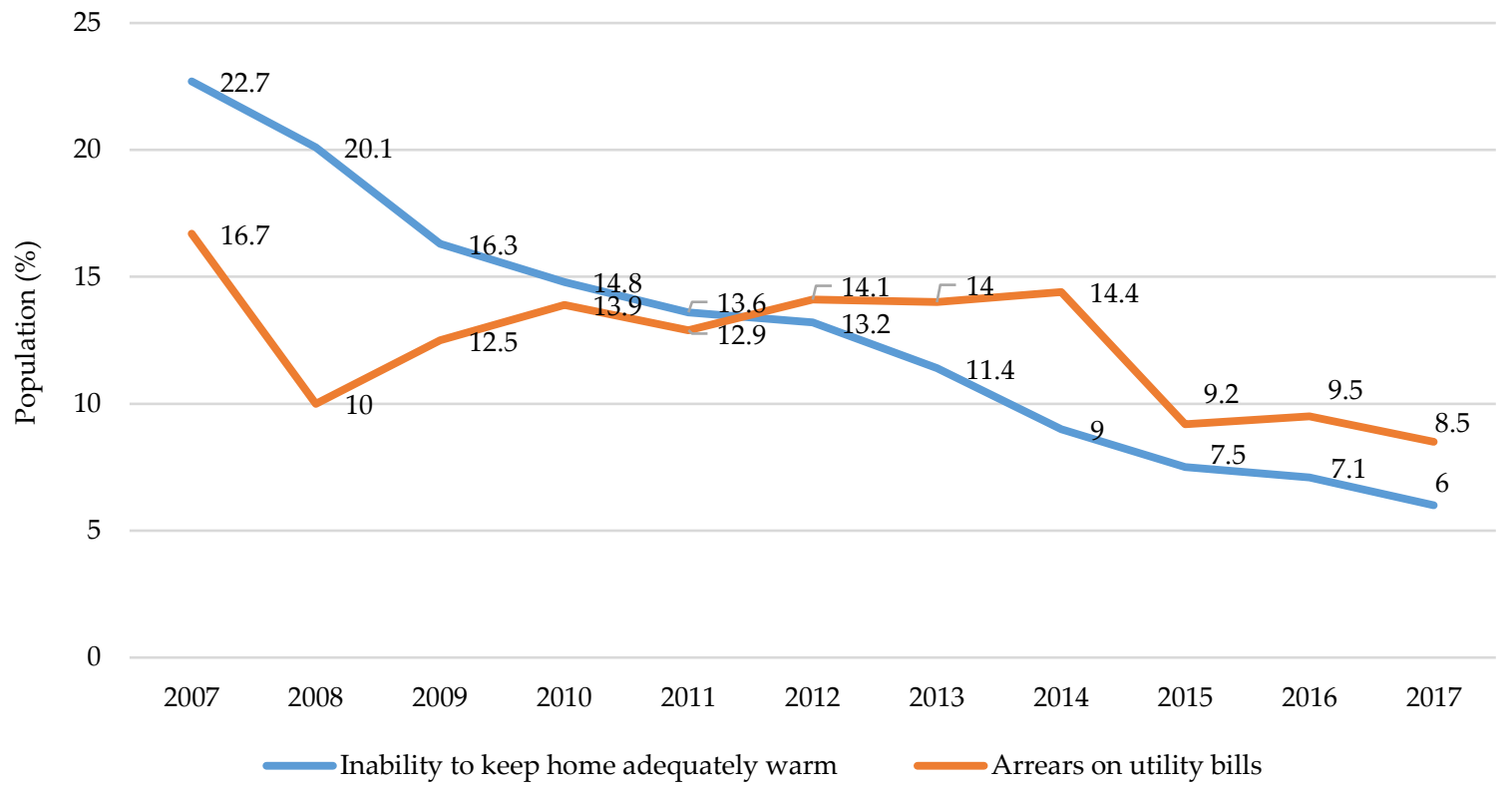

Figure 3. "Inability to keep home adequately warm" and "Arrears on utility bills" in Poland in 20072017 3. (Energy Poverty Observatory 2019b)

According to data of the EU Energy Poverty Observatory, the difficulty in maintaining an adequate temperature in the place of residence is becoming less and less of a problem. In 2007-2017, the percentage of the population declaring such a problem decreased in Poland by 16.7 p.p. The research shows that in 2017 six percent of the population of Poland considered the need for keeping their homes adequately warm to be satisfied insufficiently. The percentage of people declaring problems with paying their energy bills also decreased. In this case, the decrease in the investigated period was smaller -8.2 p.p. It is worth noting that there is a clear downward trend in the first indicator (inability to keep home adequately warm). In turn, the second indicator distinctly decreased after 2014 (an increase in the value of this indicator was recorded in 2008-2014).

The calculations presented above show a clear improvement with respect to energy poverty in Poland. In the last decade, there was not only a decrease in the extent of the overall poverty, but also in the extent of energy poverty. There is no doubt that this resulted from an improvement in incomes, as evidenced by the dynamics of changes in income and declining indicators regarding expenditures on energy purposes in relation to incomes. The improvement of incomes in Poland in recent years was achieved also thanks to the "Family 500 plus" program. This program has been implemented since 1 April 2016 and is designed to help families raise children through monthly parental benefits for each child in the family in the amount of PLN 500 (Ruzik-Sierdzińska 2018). Programs aimed at improving the technical infrastructure (subsidies for thermomodernization of buildings, financial incentives for RES development, etc.) are also important for reducing the energy poverty (Dzikuć et al. 2017; Dzikuć and Dzikuć 2019). This is very important because many apartments are located in uninsulated buildings. Thermomodernization of a significant part of houses in Poland also needs to be performed again. There are few residential buildings in Poland, especially in rural areas, with a high and very high standard of thermal insulation. The low technical standard of buildings leads to an increase in energy consumption (Piwowar 2019).

However, the positive trend in reducing the energy poverty may be hampered by an increase in the price of electricity, which, combined with the economic slowdown, can intensify the problems related to energy poverty. Introduction of widespread trade in $\mathrm{CO}_{2}$ emission permits as well as drastic reduction of emission levels in the EU and individual countries lead to an increase in prices of $\mathrm{CO}_{2}$ emission permits and contribute to higher energy prices (Dzikuć, Tomaszewski 2016; Rosicki 2018). In Poland, due to the dependence of energy production on coal, the rate of $\mathrm{CO}_{2}$ price pass-through to energy prices will be the highest in the EU, which will result in an increase in the expenditures on 
energy (Jurdziak and Kawalec 2011; Woźniak 2012; Jurdziak 2012). Thus, it becomes necessary to continue monitoring the problems of energy poverty, especially in the social groups and areas with relatively low incomes. In Poland, this concerns mainly rural areas, especially farmer's households (Piwowar and Dzikuć 2019; Piwowar 2019b). This makes it necessary to prepare integrated and sustainable scenarios and action plans for improving the energy efficiency and counteracting the energy exclusion.

\section{Conclusions}

The difficulty in satisfying the basic energy needs in the place of residence is a problem not only in countries with a relatively low level of social and economic development. Energy poverty is a serious problem in EU countries, including Poland. This paper describes the phenomenon of energy poverty in Poland. The main point is to show the differences in this phenomenon in statistical terms, based on data from 2007-2017.

The analyses show that the level of the indicators decreased significantly in the examined period of time. Particularly positive changes were observed in the case of the "Inability to keep home adequately warm" indicator. As the income of the population increases, the structure of expenditures changes. It is worth emphasizing here that the share of energy expenditures in the structure of the total expenditures in Poland decreased in the analysed period only by $0.3 \mathrm{pp}$ and was $10.7 \%$ in 2017. In turn, the share of expenditures on energy in the disposable income decreased in 2007-2017 by 1.2 p.p.

The changes in electricity prices in Poland anticipated in the coming years mean that the energy sector will have to face the transformations related to climate change, as well as problems associated with energy security and poverty. This also requires involving the local and national authorities as well as monitoring the situation, including the development of scenarios for the expected increase in electricity prices. Particular attention should be paid to helping the economically weakest households.

This section is not mandatory but can be added to sum up the topic if results and discussion sections are long or complex.

Acknowledgments: This study was conducted and financed in the framework of the research project "Socioeconomic, environmental and technical determinants of the energy poverty in rural areas in Poland", granted by the National Science Centre in Poland, program OPUS, grant No. 2018/31/B/HS4/00048.

\section{References}

Adusah-Poku Frank, Takeuchi Kenji. 2019. Energy poverty in Ghana: Any progress so far? Renewable and Sustainable Energy Reviews: 112, 853-864.

Aristondo Oihana, Onaindia Eneritz. 2018. Inequality of energy poverty between groups in Spain. Energy: 153, 431-442.

Bouzarovski Stefan, Petrova Saska. 2015. A global perspective on domestic energy deprivation: Overcoming the energy poverty-fuel poverty binary. Energy Research \& Social Science: 10, 31-40.

Brown James H., Burnside William R., Davidson Ana D., DeLong John P., Dunn William C., Hamilton Marcus J., Mercado-Silva Norman, Nekola Jeffrey C., Okie Jordan G., Woodruff William H., Zuo Wenyun. 2011. Energetic Limits to Economic Growth, BioScience: 61(1), 19-26. https://doi.org/10.1525/bio.2011.61.1.7

Charlier Dorothee, Legendre Berangere. 2019. A multidimensional approach to measuring fuel poverty. The Energy Journal: 40(2). https://10.5547/01956574.40.2.bleg

Dagoumas Athanasios, Kitsios Fotis. 2014. Assessing the impact of the economic crisis on energy poverty in Greece. Sustainable Cities and Society: 13, 267-278.

Dzikuć Maciej, Dzikuć Maria, Siničáková Marianna. 2017. The social aspects of low emission management in the Nowa Sól district. Management: 21(1), 237-249.

Dzikuć Maciej, Dzikuć Maria. 2019. Ekonomiczne determinanty ograniczenia emisji benzo[a]pirenu na obszarze Środkowego Nadodrza. Przemyst Chemiczny: 98(4), 600-603 [In Polish].

Dzikuć Maciej, Tomaszewski Marek. 2016. The effects of ecological investments in the power industry and their financial structure: a case study for Poland. Journal of Cleaner Production: 118, 48-53.

Energy Poverty Observatory. 2019a. Available online: https://www.energypoverty.eu/indicator?primaryId=1462\&type=line\&from=2004\&to=2018\&countries=PL\& 
disaggregation=none;https://ec.europa.eu/eurostat/statisticsexplained/index.php/Glossary:At-risk-ofpoverty_rate (accessed on 2 December 2019).

Energy Poverty Observatory. 2019b. Available online: https://www.energypoverty.eu/indicator?primaryId=1462\&type=line\&from=2004\&to=2018\&countries=PL\& disaggregation=none (accessed on 2 December 2019).

Eurostat. 2019a. Available online: https://ec.europa.eu/eurostat/statisticsexplained/index.php?title=People_at_risk_of_poverty_or_social_excl usion\&oldid=434278 (accessed on 2 December 2019).

Eurostat. 2019b. Available online: https:/ec.europa.eu/eurostat/web/products-eurostat-news/-/EDN-201810171?inheritRedirect=true (accessed on 2 December 2019).

González-Eguino Mikel. 2015. Energy poverty: An overview. Renewable and Sustainable Energy Reviews: 47, 377385.

Jász Krisztina. 2010. Poverty and social Exclusion in the rural areas of Hungary. Eastern European Countryside: 16, 157-174.

Jurdziak Leszek, Kawalec Witold. 2011. Wysokie ceny na rynku pozwoleń na emisje $\mathrm{CO}_{2}$ zagrożeniem dla rozwoju kraju i przyczyną zmniejszenia zasobów węgla brunatnego. Przegląd Górniczy: 10, 97-104 [In Polish].

Jurdziak Leszek. 2012. Czy grozi nam ubóstwo? Analiza potencjalnych skutków unijnej polityki walki z globalnym ociepleniem dla gospodarstw domowych w Polsce. Polityka Energetyczna: 15(3), 23-50 [In Polish].

Libor Grzegorz, Bouzarovski Stefan. 2018. The socio-demographic dimensions of energy poverty: a case study from Bytom, Poland. Urban Development Issues: 57(1), 63-77.

Marchand Robert, Genovese Andrea, Koh SC Lenny, Brennan Alan. 2019. Examining the relationship between energy poverty and measures of deprivation. Energy Policy: 130, 206-217. https://doi.org/10.1016/j.enpol.2019.03.026

Maxim Alexandru, Mihai Costică, Apostoaie Constantin-Marius, Popescu Cristian, Istrate Costel, Bostan Ionel. 2016. Implications and measurement of energy poverty across the European Union. Sustainability: 8(5), 483.

Panek Tomasz. 2008. Ubóstwo i nierówności: Dylematy pomiaru. Warszawa: Instytut Statystyki i Demografii SGH, pp. 1 [In Polish].

Piwowar Arkadiusz, Dzikuć Maciej. 2019. Development of Renewable Energy Sources in the Context of Threats Resulting from Low-Altitude Emissions in Rural Areas in Poland: A Review. Energies:12, 3558. https://doi:10.3390/en12183558

Piwowar Arkadiusz. 2019a. Buildings in agricultural holdings in the context of low-carbon development of the agriculture and rural areas in Poland. Education Excellence and Innovation Management through Vision 2020. 33rd IBIMA Conference Proceedings, pp. 322-331.

Piwowar Arkadiusz. 2019b. Social communication and education related to the problems associated with lowaltitude emissions in rural areas. In Epiphenomenalism Borderland (Eds.. R. Woźniak, T. Zaborowski). Gorzów Wlkp. - Poznań: Instytut Badań i Ekspertyz Naukowych w Gorzowie Wlkp., pp. 90-102.

Pojar Jan. 2018. Programme to reduce energy poverty in the Czech Republic. Energy Policy: 115(2), 131-137.

Romero Jose Carlos, Linares Pedro, López Xiral. 2018. The policy implications of energy poverty indicators. Energy Policy: 115, 98-108.

Rosicki Remigiusz. 2018. Rynek energii elektrycznej w Polsce. Prognozy zapotrzebowania na energię elektryczną i prognozy cen energii elektrycznej. Środkowoeuropejskie Studia Polityczne: 1, 141-165 [In Polish].

Ruzik-Sierdzińska Anna. 2018. Krótkookresowe skutki programu Rodzina 500+. Studia z Polityki Publicznej: 17(1), 63-76 [In Polish].

Santos Maria Emma, Dabus Carlos, Delbianco Fernando. 2019. Growth and poverty revisited from a multidimensional perspective. The Journal of Development Studies: 55(2), 260-277.

Statistic Poland. 2019a. Available online: https://stat.gov.pl/obszary-tematyczne/warunki-zycia/dochodywydatki-i-warunki-zycia-ludnosci/budzety-gospodarstw-domowych-w-2013-r-,9,8.html (accessed on 29 November 2019).

Statistic Poland. 2019b. Available online: https://stat.gov.pl/obszary-tematyczne/warunki-zycia/dochodywydatki-i-warunki-zycia-ludnosci/budzety-gospodarstw-domowych-w-2017-r-,9,12.html (accessed on 29 November 2019).

Tàbara J. David, Takama Takeshi, Mishra Manisha, Hermanus Lauren, Andrew Sean Khaya, Diaz Pacia, Ziervogel Gina, Lemkow Louis. 2019. Micro-solutions to global problems: understanding social processes to eradicate energy poverty and build climate-resilient livelihoods. Climatic Change, pp.1-15. https://doi.org/10.1007/s10584-019-02448-z 
Węglarz Arkadiusz, Kubalski Grzegorz, Owczarek Dominik. 2014. Propozycje mechanizmów wsparcia procesu przeciwdziałania zjawisku ubóstwa energetycznego w Polsce, Warszawa: Instytut na Rzecz Ekorozwoju, pp. 1-48 [In Polish].

Woźniak Justyna. 2012. Wpływ kosztów wykupu pozwoleń na emisję $\mathrm{CO}_{2}$ na wzrost ceny energii elektrycznej w Polsce. Polityka Energetyczna: 15(4), 139-149 [In Polish].

Zhang Ruixin, Naceur Sami Ben. 2019. Financial development, inequality, and poverty: Some international evidence. International Review of Economics \& Finance: 61, 1-16. 